\title{
Human papilloma virus DNA in Nongenital Seborrheic Keratosis
}

\author{
Ebrahim Soleymani ${ }^{1}$, Parviz Toosi ${ }^{2}$, Fariba Alaei ${ }^{2}$, Mastaneh Alaei ${ }^{3, *}$ \\ ${ }^{1}$ AJA University of Medical Sciences, Tehran, IR Iran \\ ${ }_{3}^{2}$ Shahid Beheshti University of Medical Sciences, Tehran, IR Iran \\ 3 Blood Transfusion Research Center, High Institute for Research and Education In Transfusion Medicine, Tehran, IR Iran \\ *Corresponding author: Mastaneh Alaei, IBTO bldg, Hemmat Exp. Way, Next to Milad Tower, Tehran, IR Iran. Tel: +98-2188601501-30, Fax: +98-2188601555, E-mail: alaeimastaneh@
} hotmail.com.

Received: December 3, 2012; Revised: July 12, 2013; Accepted: October 31, 2013

\begin{abstract}
Background: Seborrheic Keratoses (SK) are common, benign and often multiple skin tumors with disputed etiology. A follicular origin, late onset nevoid disturbance or local arrest in maturation of keratinocytes have been proposed. Human papilloma virus (HPV) has been detected in a small number of cases, particularly those from the genital region.

Objectives: The aim of our study was to evaluate the presence of HPV 6/11,31 and 33 DNA in SK of nongenital regions.

Materials and Methods: We examined 49 biopsy specimens of nongenital SK for the presence of HPV DNA using PCR technique (INNOLiPA HPV Genotyping Extra).

Results: The SK specimens $(n=49)$ were negative for all HPV probes (types 6/11, 31 and 33) tested. Genital wart specimens $(n=2)$ were positive for types 6/11, 31 and 33 HPV DNA (positive controls); while chronic dermatitis specimens $(n=10)$ were negative for all HPV types (negative controls).

Conclusions: Our study results demonstrate that HPV types 6/11,31 and 33 cannot be causative in SK of nongenital regions.

Keywords: Human Papilloma Virus; Seborrheic Keratosis; Polymerase Chain Reaction
\end{abstract}

\section{Background}

Human papilloma virus (HPV) has been detected in benign and malignant skin tumors such as warts, epidermodysplasia-verruciformis, trichilemmomas, syringomas, skin tags and etc. (1-3). Seborrheic keratoses are common usually multiple skin tumors often being confused with warts in their clinical or histological appearance. Various studies have evaluated the role of HPV in the pathogenesis of seborrheic keratosis according to these similarities (4-9).

Tsambaos et al. showed HPV genome in 34/173 (19.65\%) of specimens of nongenital SK using in situ hybridization (ISH) technique (4). Wen-Yuan Zhu et al. detected HPV DNA (6/11and 33) in 23 (53\%) of cases of the genital region SK and one (3\%) case of nongenital region SK using PCR (5). Another study revealed HPV-DNA in 30/104 (28.8\%) cases of nongenital SK by ISH and showed HPV18 in $87(83.7 \%)$, HPV-6 in 81 (77.9\%) and both HPV-18 and -6 in $73(70.2 \%)$ of cases by PCR analysis (6). Zhao et al. found wart like histologic changes in 4 of 89 specimens of nongenital SK. They confirmed HPV infection in these lesions using electron microscopy (7). Yet another study demonstrated HPV DNA 6, 11, 16, 18 and 33 in 24 of 57 ( $42 \%$ ) SK-like lesions from the genital region using specific hybridization (8). Eun-so Lee et al. showed absence of HPV DNA in 40 cases of nongenital SK using in situ PCR (9).

\section{Objectives}

We examined 49 biopsy specimens of nongenital SK for HPV DNA types 6/11, 31 and 33 using PCR examination method.

\section{Materials and Methods}

For this cross-sectional study, formalin-fixed, paraffinembedded, biopsy specimens of all patients with pathologic diagnosis of nongenital SK (total of 50 cases) admitted to the dermatology clinic of Shohada Hospital affiliated to Shahid Beheshti University of Medical Sciences, between April 2009 to April 2010, were selected for examination. Due to the small size, one of the specimens was detached from the paraffin block and was broken before the main study.

All specimens showed the histological appearance of SK. The diagnoses were reconfirmed after examination of histological slides by two other pathologists. We used 2 specimens of genital wart as our positive controls and 10 specimens of skin with chronic dermatitis as our negative controls.

In order to prepare tissue samples for PCR analysis, 0.5 $\mu \mathrm{m}$ thick cut tissue sections were deparaffinized in a micro-tube with $1200 \mu \mathrm{L}$ xylene, followed by dehydraion with $100 \%$ ethanol and centrifugation in 13,400 rpm for five minutes. Supernatant was drained and centrifuga-

Implication for health policy/practice/research/medical education:

Evaluation of patients with a relatively common dermatologic lesion for virus involvement can affect our preventive policies.

Copyright @ 2014, Pediartric Infections Research Center. This is an open-access article distributed under the terms of the Creative Commons Attribution License, which permits unrestricted use, distribution, and reproduction in any medium, provided the original work is properly cited. 
tion was repeated. Then the microtubes were cooled to $37^{\circ} \mathrm{C}$. QIA amp mini kit was used for DNA purification from tissues and PCR analysis was performed via INNOLiPA HPV Genotyping Extra kit.

The INNO-LiPA HPV Genotyping Extra is based on the principle of reverse hybridization. Part of the $\mathrm{L} 1$ region of HPV genome is amplified using SPF10 primers, and the resulting biotinylated amplicons are then denaturated and hybridized with specific oligonucleotide probes. An additional primer pair for the amplification of the human HLA-DPB1 gene is added to monitor sample quality and extraction. All probes are immobilized as parallel lines on membrane strips. After hybridization and stringent washing, streptavidin-conjugated alkaline phosphatase is added, which binds to any biotinylated hybrid previously formed.

Incubation with 5-Bromo 4-chloro 3 -indoliphosphate p-toluidine nitrablue tetrazolium (BCIP/NBT) chromogen yields a purple precipitate and the results can be interpreted visually or by using the LiRAS for LiPA HPV software.

\section{Results}

The SK specimens were obtained from 49 patients, 29 men and 20 women. Biopsy specimens were taken from face $(n=29)$, trunk $(n=11), \operatorname{scalp}(n=7)$, upper extremities $(n=1)$ and lower extremities $(n=1)$. Histologic subtypes showed 26 acanthotic, 10 irritated, 7 hyperkeratotic, 6 reticulated and one clonal type of SK. Histologic slides of 2 cases of genital wart and 10 cases of chronic dermatitis were reviewed and examined as positive and negative controls respectively.

HPV DNA was not detected by PCR analysis of any tissue specimen taken from patients with SK $(n=49)$ or skin with chronic dermatitis $(n=10)$, while samples taken from patients with genital wart $(n=2)$ showed DNA bands of HPV6/11, 31 and 33 by PCR examination.

\section{Discussion}

In our study, PCR analysis of specimens did not show HPV genomes type 6/11, 31 or 33 in the nongenital SK tissue samples $(n=49)$. This result is similar to the result of Eun-so Lee and his colleagues (9) but is in contrast to the results of Tsambaos et al. who showed HPV genome in 34/173 (19.65\%) of specimens of nongenital SK using ISH (4). It is also in contrast to the results of Wen-Yuan Zhu et al. who detected HPV DNA (6/11 and 33) in one (3\%) case of nongenital SK using PCR (5) and another study revealing HPV DNA in 30/104 (28.8\%) cases of nongenital SK by ISH and HPV-6 in 81(77.9\%) of nongenital SK cases by PCR analysis (6). Also Zhao et al. confirmed HPV infection in 4 of 89 cases of nongenital SK by electron microscopy which is in contrast to our PCR findings (7).

We used a sensitive (97.8\%) and specific (98.17\%) method to evaluate HPV genomes (type 6/11, 31 and 33) on tissue specimens. As our positive controls (genital warts, $\mathrm{n}=2$ ) showed positive bands for HPV and negative controls (skin with chronic dermatitis, $n=10$ ) failed to show it, we do not believe that our negative results are technical errors.

In conclusion, according to our study, and finding no association between nongenital SK and HPV types, it seems that 4 types of HPV (6/11, 31 and 33)are not causative agents for nongenital SK. Further studies using fresh samples and evaluation of other types of HPV DNA are required to clarify the role of HPV in the pathogenesis of nongenital SK.

\section{Acknowledgements}

There is no acknowledgments.

\section{Authors' Contribution}

1. Study concept and design: Ebrahim Soleimani, Mastaneh Alaei, 2. Drafting of the manuscript: Fariba Alaei, Mastaneh Alaei, 3. Critical revision: Mastaneh Alaei, Ebrahim Soleimani, Fariba Alaei, 4.Study supervision: Parviz Toosi.

\section{Financial Disclosure}

Therer is no conflict of interest for this study.

\section{Funding/Support}

The funds of this study were paid by Dermatology Research Center of Shahid Beheshti University of Medical Sciences. We had no other supporters or sponsors.

\section{References}

1. Assadoullina A, Bialasiewciz AA, deVilliers EM, Richard G. Detection of HPV-20,HPV-23,and HPV-DL332 in a solitary eyelid syringoma. . Am J Ophthalmol. 2000;129:99-101.

2. Dianzani C, Calvieri S, Pierangeli A, Imperi M, Bucci M, Degener AM. The detection of human papillomavirus DNA in skin tags. $\mathrm{Br}$ JDermatol. 1998;138(4):649-51.

3. Rohwedder A, Keminer O, Hendricks C, Schaller J. Detection of HPV DNA in trichilemmomas by polymerase chain reaction. $J$ Med Virol. 1997;51(2):119-25.

4. Tsambaos D, Monastirli A, Kapranos N, Georgiou S, Pasmatzi E, Stratigos A, et al. Detection of human papillomavirus DNA in nongenital seborrhoeic keratoses. Arch Dermatol Res. 1995;287(6):612-5.

5. Zhu WY, Leonardi C, Penneys NS. Detection of human papillomavirus DNA in seborrheic keratosis by polymerase chain reaction. JDermatol Sci. 1992;4(3):166-71.

6. Gushi A, Kanekura T, Kanzaki T, Eizuru Y. Detection and sequences of human papillomavirus DNA in nongenital seborrhoeic keratosis of immunopotent individuals. J Dermatol Sci. 2003;31(2):143-9.

7. Zhao YK, Lin YX, Luo RY, Huang XY, Liu MZ, Xia M, et al. Human papillomavirus (HPV) infection in seborrheic keratosis. Am JDermatopathol. 1989;11(3):209-12.

8. Leonardi CL, Zhu WY, Kinsey WH, Penneys NS. Seborrheic keratoses from the genital region may contain human papillomavirus DNA. Arch Dermatol. 1991;127(8):1203-6.

9. Lee ES, Whang MR, Kang WH. Absence of human papillomavirus DNA in nongenital seborrheic keratosis. J Korean Med Sci. 2001;16(5):619-22. 